\title{
VENTILATION IN TWO SPECIES OF LIZARDS DURING REST AND ACTIVITY
}

\author{
ALBERT F. BENNETT* \\ Department of Zoology, University of Michigan, Ann Arbor, Michigan 48104, U.S.A.
}

(Received 22 Yanuary 1973)

\begin{abstract}
Oxygen consumption, ventilation frequency and tidal volume were measured simultaneously in two lizards, Varanus gouldii and Sauromalus hispidus, during rest and maximal activity.

2. Ventilation frequency and tidal volume are almost identical in these species. The greater oxygen consumption during activity of Varanus results from a greater oxygen extraction from ventilated air.

3. Increased oxygen consumption during activity results from increments in tidal volume; ventilation frequency remains constant.

4. The thermal and weight dependence of ventilatory variables in reptiles is analyzed.

5. The capacity for oxygen extraction by saurian lungs is similar to that of mammals and birds, even at identical ventilation rates, in spite of their simple lung morphology.
\end{abstract}

\section{INTRODUCTION}

IN COMPARISON to the complex lung structure of mammals and birds, that of most lizards is relatively simple and poorly vascularized (see Milani, 1894, and Wolf, 1933, for extensive anatomical descriptions). Most saurian lungs are relatively simple sacs: the respiratory area is small and confined to the anterior portion of the lung. Intrapulmonary bronchi or other anatomical specializations for air transport are lacking. The posterior part of the lung is devoid of air cells and may be homologous to the unvascularized air sacs of birds (Wolf, 1933). The entire organ is not generally considered efficient in its ability to extract oxygen from ventilated air even under resting conditions: blood passing through the lungs of most reptiles attains only 60-80 per cent of its potential oxygen capacity (Steggerda \& Essex, 1957; White, 1959; Andersen, 1961; Tucker, 1966). The increased energetic demands during activity in most reptiles are met primarily by anaerobic metabolism, increased oxygen consumption being insufficient to supply these needs (Moberly, 1968; Bennett, 1971; Wilson, 1971; Bennett \& Dawson, 1972; Bennett \& Licht, 1972).

An exception to most of these generalizations concerning lung structure and metabolic physiology is the saurian family Varanidae (genus Varanus). Its members

* Present address: Department of Zoology, University of California, Berkeley, California 94720. 
are very active carnivores, which chase prey over long distances and range over considerable territory. Varanids possess high rates of oxygen consumption during activity (Bartholomew \& Tucker, 1964; Bennett, 1972b) and do not rely extensively on anaerobic metabolism (Bennett, 1973). Their lung structure is much more complex than that of other reptiles (Milani, 1894; Wolf, 1933; Mertens, 1942; Kirschfeld, 1970). Varanus possess cartilage-lined intrapulmonary bronchi and extensive spongy, alveolar-like cells throughout the entire lung. Wolf (1933) suggested that varanid lungs were possible precursors to those of the birds and mammals. Although varanid lizards are far removed phylogenetically from the ancestral lines leading to these groups, their lung structure may well be analogous to that of the highly active animals which were.

A comparative study was undertaken to determine the physiological bases of the greater capacity for activity and oxygen consumption evident in varanid lizards. More representative of lizards as a group is the family Iguanidae, the members of which are probably not greatly morphologically different from the ancestors of the order Squamata (Romer, 1956). Iguanid lizards are characterized by simple lung structure, low aerobic scope and considerable anaerobiosis during activity. Oxygen metabolism and transport during rest and activity were examined in an iguanid, Sauromalus hispidus, and a varanid, Varanus gouldii, of similar size and thermal preferendum $\left(37-38^{\circ} \mathrm{C}\right)$ (Bennett, 1971, 1972a, b, 1973). This portion of that study examines the relationship between ventilation, oxygen consumption, and anaerobic metabolism in order to determine whether the first of these variables is closely linked with the others, i.e. whether any correlation exists between metabolic and ventilatory factors. Ventilation frequency $(f)$, tidal volume $\left(V_{\mathrm{T}}\right)$, and oxygen consumption $\left(\dot{V}_{\mathrm{O}_{2}}\right)$ were measured simultaneously under conditions of rest and maximal activity. The interrelations of these factors are examined and some general patterns for ventilatory variables in reptiles are formulated and discussed.

\section{MATERIALS AND METHODS}

Fifteen adult $S$. hispidus (mean weight, $574 \mathrm{~g}$ ) and ten adult $V$. gouldii (mean weight, $674 \mathrm{~g}$ ) were used in these experiments. Conditions of animal maintenance have been reported previously (Bennett, 1972b).

Oxygen consumption, ventilation frequency and tidal volume were measured simultaneously on resting and active animals at body temperatures $\left(T_{\mathrm{b}}\right)$ between 15 and $42^{\circ} \mathrm{C}$. A mask of small volume $\left(100,175\right.$ or $\left.400 \mathrm{~cm}^{3}\right)$, which covered the entire head and neck, was fashioned from rubber "wet-suit" material and was fastened to the pectoral region of the animals with contact cement. The masks did not interfere with normal ventilation since they were anchored to an immobile portion of the pectoral musculature and did not touch the gular or thoracic region. They contained in-current and ex-current air ports and were air- and light-tight. A masked animal was fitted with a rectal thermocouple for measurement of $T_{\mathrm{b}}$. It was tied to a restraining board and placed in a constant-temperature cabinet (regulated at $\pm 0.5^{\circ} \mathrm{C}$ ) before noon on the day of experimentation. All measurements were made at night after 20.00 hours. Dry air was metered continuously through the mask at 150 $1000 \mathrm{~cm}^{3} / \mathrm{min}$ during the equilibration time. 
Oxygen consumption was determined by monitoring the dry, $\mathrm{CO}_{2}$-free ex-current air stream with a Beckman paramagnetic oxygen analyzer. Rates of oxygen consumption were calculated according to the method described by Hill (1972). Ventilation frequency and tidal volume were monitored by the interposition of a glass $U$-tube $(16 \mathrm{~cm}$ high $\times 1.8 \mathrm{~cm}$ dia.), partially filled with water, in the ex-current air line. The air stream flowed into and out of the same arm of the U-tube, and the rise and fall of the water level accurately reflected the ventilatory movements of the animal. Ventilation frequency was determined by visually counting the displacements of the water column and was recorded in breaths $/ \mathrm{min}$. Tidal volume was obtained by measuring the displacement of the water column during the second portion of the triphasic ventilation cycle (see Templeton \& Dawson, 1963). The magnitude of the displacement was calibrated by injecting known volumes of air into the in situ mask at a rate equivalent to that of normal ventilation and measuring the displacement of the column. Tidal volume was recorded in $\mathrm{cm}^{3}$ air (BTPS)/breath. The volume and number of breaths were measured over a period of several minutes; these remained very constant during that period. Below $20^{\circ} \mathrm{C}$, Sauromalus occasionally became apneustic and periods of measurement were extended to cover several cycles of breathing and nonbreathing periods.

During the experimental period, oxygen consumption of the undisturbed, resting animal was monitored continuously for an hour and ventilation and tidal volume were measured every $15 \mathrm{~min}$ during that period. All observations were averaged to yield resting values. To obtain activity and maximal levels of oxygen consumption, safety-pin electrodes were implanted in the hind limbs of the animals. A lizard was first stimulated by general handling of the limbs and tail. Sometimes a series of electric shocks $\left(2-10 \mathrm{~V}, 10 \mathrm{sec}^{-1}\right)$ were delivered with a stimulator if the animal became refractory to further handling. Stimulation continued in this manner for $7 \mathrm{~min}$; oxygen consumption and $T_{\mathrm{b}}$ were monitored continuously for the entire period. Ventilation frequency and tidal volume were measured immediately at the end of stimulation.

All linear and polynomial equations reported are the best computed least-squares fit to the data. If a function was not obviously linear after logarithmic transformation, polynomial regressions of increasingly higher degree were computed to describe the data until no further significant improvement was obtained. In practice, this never required more than a second-order regression. Correlations are measured by either a Spearman rank correlation or a Student's $t$-test on the correlation coefficient between the two variables.

\section{RESULTS}

\section{Species comparisons}

Data on oxygen consumption have been reported and discussed previously (Bennett, 1972b). They are summarized in Fig. 1. At preferred $T_{b}, 37-38^{\circ} \mathrm{C}$, resting metabolic rates are nearly identical in the two species; during activity, Varanus is able to consume twice as much oxygen as Sauromalus.

There are almost no interspecific differences in ventilation frequency (Figs. 2 and 3 ) and tidal volume (Figs. 4 and 5) in resting and active Sauromalus and Varanus. The sole exception is the lower resting ventilation frequency of Varanus at low $T_{\mathrm{b}}$. Consequently, the product of these factors, the minute volume, $V_{E}$, the amount of air ventilated per minute (BTPS), is also nearly identical in resting and active animals of both species (Figs. 6 and 7). A particularly interesting aspect is that the ventilation rate in active animals at preferred $T_{\mathrm{b}}$ is identical, although oxygen consumption by Varanus is twice as high as that of Sauromalus. 


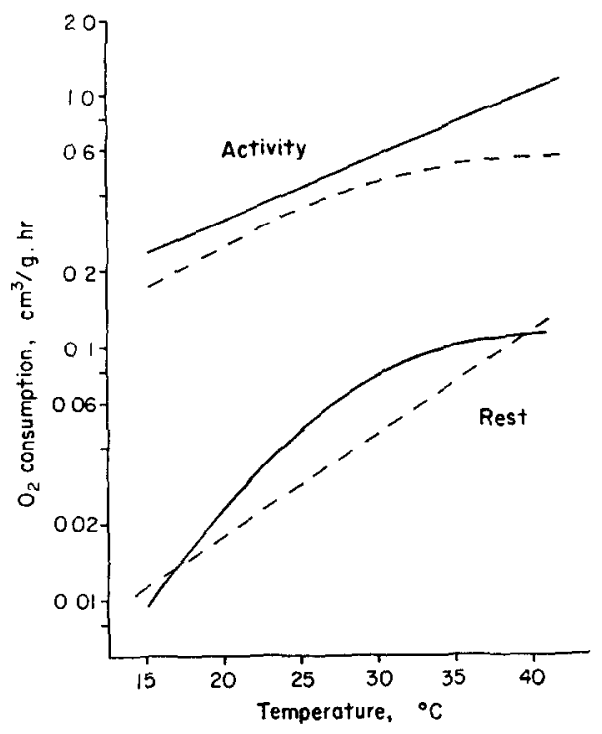

FIG. 1. Standard and maximal oxygen consumption during rest and activity in $V$. gouldii (solid lines) and S. hispidus (dashed lines) (data from Bennett, 1972b).

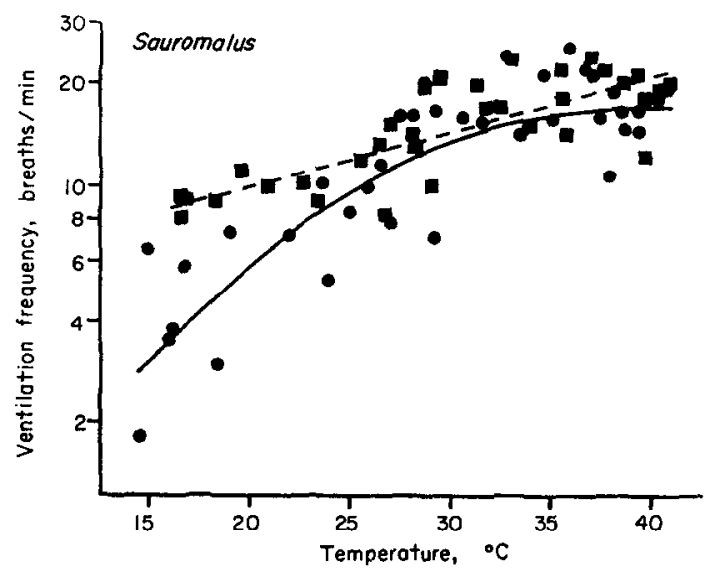

FIG. 2. Ventilation frequency in $S$. hispidus. Standard measurements are indicated by circles and a solid regression line: $\log f=-0.727+0.102 T_{\mathrm{b}}-0.00133 T_{\mathrm{b}}{ }^{2}$. Active measurements are given by squares and a dashed regression line: $\log f=$ $0.686+0.0158 T_{\mathrm{b}}$. 


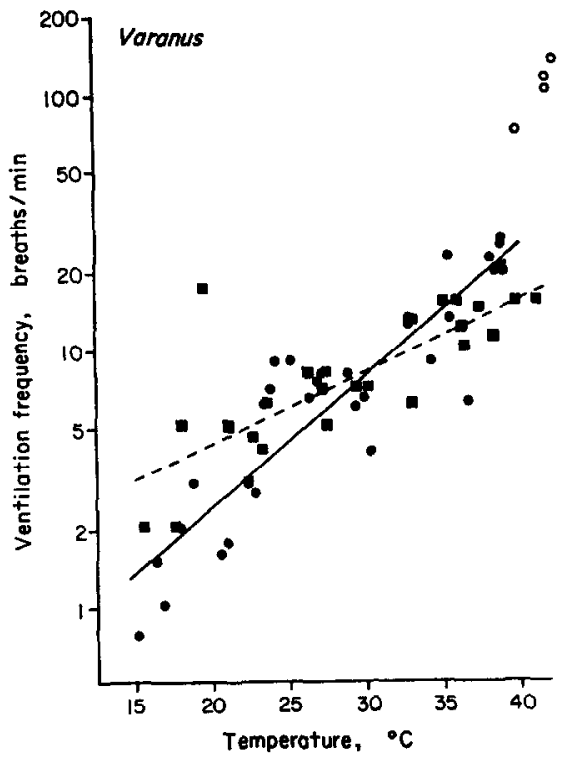

FIG. 3. Ventilation frequency in $V$. gouldii. Standard measurements are indicated by shaded circles and a solid regression line: $\log f=-0.635+0.0506 T_{\mathrm{b}}$. Active measurements are given by squares and a dashed regression line: $\log f=-0.062$ $+0.0281 T_{\mathrm{b}}$. Measurements on hyperventilating animals are indicated by unshaded circles.

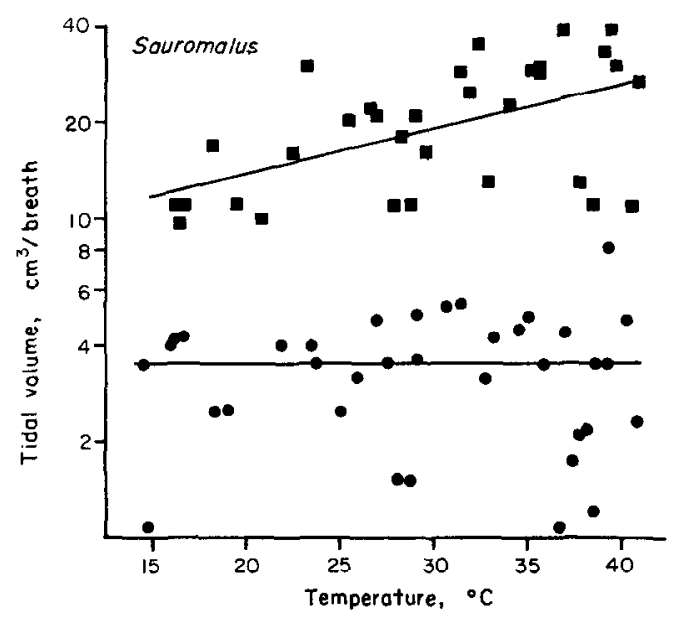

Fig. 4. Tidal volume in $S$. hispidus during rest (circles) and activity (squares). The line through the standard values is the mean for all standard data $\left(3.5 \mathrm{~cm}^{3} /\right.$ breath); the regression line through the active data is $\log V_{\mathrm{T}}=0.869+0.0137 T_{\mathrm{b}}$. 


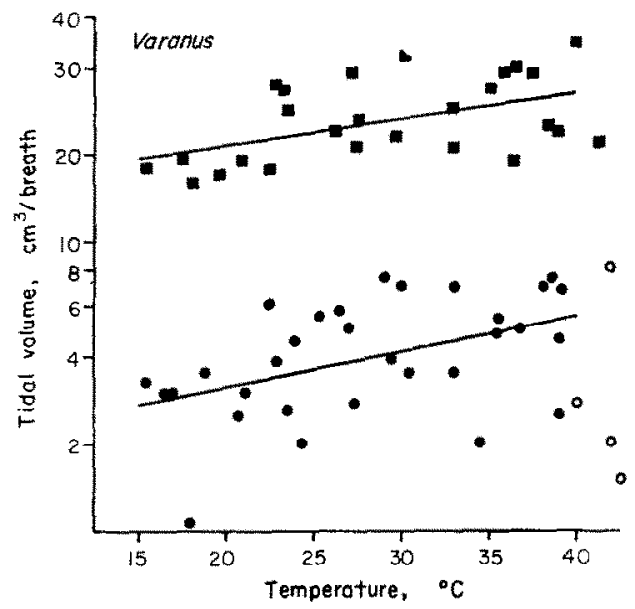

FIG. 5. Tidal volume in $V$. gouldii during rest (shaded circles; $\log V_{\mathrm{T}}=0 \cdot 240$ $+0.0127 T_{\mathrm{b}}$ ) and activity (squares; $\log V_{\mathrm{T}}=1 \cdot 156+0.0090 T_{\mathrm{b}}$ ). Unshaded circles represent measurements on hyperventilating animals.

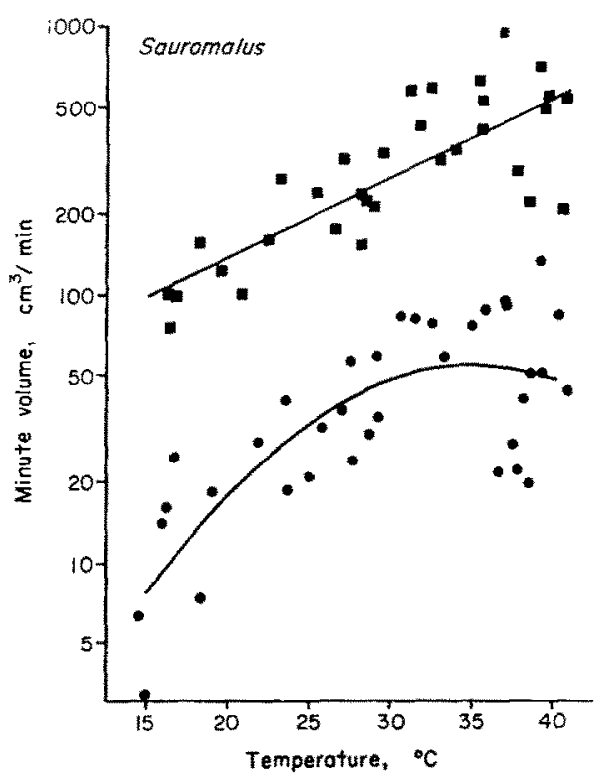

Frg. 6. Minute volume in $S$. hispidus during rest (circles; $\log V_{\mathrm{E}}=-0.841$ $0.147 T_{\mathrm{b}}-0.00209 T_{\mathrm{b}}{ }^{2}$ ) and activity (squares; $\log \dot{V}_{\mathrm{T}}=1.554+0.0295 T_{\mathrm{b}}$ ). 


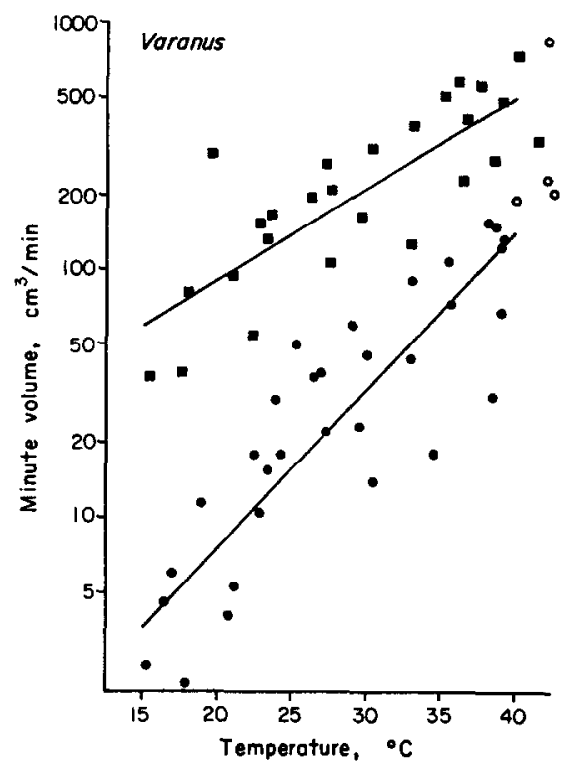

FIG. 7. Minute volume in $V$. gouldii during rest (shaded circles; $\log V_{\mathbf{E}}=-0.395$ $+0.0636 T_{\mathrm{b}}$ ) and activity (squares; $\log \bar{V}_{\mathbf{E}}=1.218+0.0371 T_{\mathrm{b}}$ ). Unshaded circles indicate measurements on hyperventilating animals.

\section{Effects of activity}

Although oxygen consumption increases five- to twenty-fold above resting levels during activity, ventilation frequency does not change in either species. Tidal volume increases greatly and represents the principal ventilatory adjustment to increased oxygen demands. The greater minute volumes during activity reflect the increments in tidal volumes.

TABle 1-Thermal DePENDENCE of Respiratory variables in Sauromalus hispidus and Varanus gouldii

\begin{tabular}{lccccc}
\hline & \multicolumn{2}{c}{ Sauromalus } & & \multicolumn{2}{c}{ Varanus } \\
\cline { 2 - 3 } \cline { 5 - 6 } & Rest & Active & & Rest & Active \\
\hline Ventilation frequency & $3.65-1.03$ & 1.44 & & 3.23 & 1.91 \\
Tidal volume & 1.0 & 1.37 & & 1.34 & 1.23 \\
Minute volume & $5 \cdot 51-0.80$ & 1.97 & & 4.32 & 2.35 \\
Oxygen consumption & 2.50 & $2 \cdot 17-1.08$ & & $6.61-1.07$ & 1.78 \\
\hline
\end{tabular}

Column entries are $Q_{10}$ values. A single $Q_{10}$ indicates a constant thermal dependence between $15-40^{\circ} \mathrm{C}$. A range of $Q_{10}$ values indicates decreasing thermal dependence with increasing temperature: the first value is the $Q_{10}$ of $15-20^{\circ} \mathrm{C}$ and the second, $35-40^{\circ} \mathrm{C}$. 


\section{Thermal effects}

The $Q_{10}$ values for these respiratory variables are given in Table 1 . Tidal volume is characterized by very low thermal dependence over a wide thermal range. Likewise, several other respiratory variables are thermally independent at high body temperatures: ventilation frequency (and, consequently, minute volume) in resting Sauromalus and oxygen consumption in resting Varanus and active Sauromalus. The thermal patterns of oxygen consumption do not correspond to those of the ventilation rate.

Thermoregulatory hyperventilation was never observed in Sauromalus at $T_{\mathrm{b}}$ as great as $42 \cdot 0^{\circ} \mathrm{C}$. Varanus begins hyperventilating at $40-41^{\circ} \mathrm{C}$.

\section{DISCUSSION}

\section{Ventilation rate in resting lizards}

The thermal patterns of ventilation frequency exhibited by Sauromalus and Varanus are characteristic of the two types of response which have been found for other lizards. The majority of species examined have ventilation frequencies of low thermal dependence $\left(Q_{10} \leqslant 1 \cdot 6\right)$ or, as in the case of Sauromalus hispidus, have broad zones of $T_{\mathrm{b}}$ in which ventilation frequency is constant: Crotaphytus collaris (Dawson \& Templeton, 1963; Templeton \& Dawson, 1963), Eumeces obsoletus (Dawson, 1960), Gerrhonotus multicarinatus (Dawson \& Templeton, 1966), Lygosoma laterale (Hudson \& Bertram, 1966), Physignathus lesueuri (Wilson, 1971), Sauromalus obesus (Crawford \& Kampe, 1971), Sceloporus occidentalis (Francis \& Brooks, 1968), Uma notata (Pough, 1969) and Xantusia vigilis (Snyder, 1971). These zones of low thermal dependence always encompass preferred $T_{\mathrm{b}}$ and strongly contrast to the thermal patterns of nearly all other physiological functions investigated in these animals. The pattern in which the logarithm of the ventilation frequency varies directly with $T_{\mathrm{b}}$ with a high thermal dependence $\left(Q_{10} \geqslant 2 \cdot 0\right)$, the relationship characteristic of most physiological variables, occurs in fewer species: Dipsosaurus dorsalis (Dawson \& Bartholomew, 1958; Moberly, 1963), Egernia cunninghami (Wilson, 1971), Lacerta spp. (Nielsen, 1961), Tiliqua rugosa (Wilson, 1971) and Uta mearnsi (Murrish \& Vance, 1968), as well as Varanus gouldii. The overall $Q_{10}$ at $30-37^{\circ} \mathrm{C}$ for ventilation frequency in all species investigated is 1.3 (see Table 2).

Unlike mammalian or avian ventilatory patterns, the lung is inflated during the interphase (rest) portion of the breathing cycle in lizards. Thus, as Templeton \& Dawson (1963) have pointed out, an increment in ventilation will decrease the total time in which the lung is inflated. A ventilation frequency of low thermal dependence may, therefore, be an adaptation to maximize the exposure of blood in the lungs to pulmonary air. There is, however, no obvious phylogenetic or ecological correlation between species possessing or lacking this low thermal dependence.

It has been suggested that ventilation frequency is inversely correlated with body size in lizards (Boyer, 1966, 1967), as is the case in mammals and birds (see 
TABLe 2-Ventilation FREQUENCIES IN LIZARDS

\begin{tabular}{lcccl}
\hline Species & $\begin{array}{c}\text { Weight } \\
(\mathrm{g})\end{array}$ & $\begin{array}{c}f\left(30^{\circ} \mathrm{C}\right) \\
\left(\mathrm{min}^{-1}\right)\end{array}$ & $\begin{array}{c}f\left(37^{\circ} \mathrm{C}\right) \\
\left(\mathrm{min}^{-1}\right)\end{array}$ & \multicolumn{1}{c}{ Reference } \\
\hline C. collaris & $30^{*}$ & 17 & 25 & Dawson \& Templeton, 1963 \\
D. dorsalis & $70^{*}$ & 18 & 35 & Dawson \& Bartholomew, 1958 \\
E. cunninghami & 253 & 22 & 38 & Wilson, 1971 \\
E. obsoletus & $30^{*}$ & 17 & 25 & Dawson, 1960 \\
G. multicarinatus & $30^{*}$ & 7 & 12 & Dawson \& Templeton, 1966 \\
Lacerta spp. & 19 & 38 & - & Nielsen, 1961 \\
L. laterale & $1 \cdot 0$ & 38 & - & Hudson \& Bertram, 1966 \\
$P$. lesueuri & 585 & 26 & 30 & Wilson, 1971 \\
$S$. hispidus & 574 & 14 & 17 & This study \\
$S$. obesus & 140 & $8 \cdot 3$ & 12 & Crawford \& Kampe, 1971 \\
$S$. occidentalis & $12 \cdot 8$ & 35 & - & Francis \& Brooks, 1968 \\
T. rugosa & 477 & $7 \cdot 2$ & 11 & Wilson, 1971 \\
U. notata & 30 & 18 & 18 & Pough, 1969 \\
$U$. mearnsi & $14^{*}$ & $19 \dagger$ & $29 \dagger$ & Murrish \& Vance, 1968 \\
$V$. gouldii & 674 & 8 & 20 & This study \\
$X$. vigilis & $1 \cdot 1$ & 6 & - & Snyder, 1971 \\
\hline
\end{tabular}

* Midpoint of weight range.

+ Acclimated to $15^{\circ} \mathrm{C}$.

Lasiewski \& Calder, 1971). Only recently has sufficient information accumulated to permit an examination of the weight dependence of ventilatory factors in this group. These data are summarized in Table 2. Least-squares regression equations of ventilation frequency at 30 and $37^{\circ} \mathrm{C}$ on body weight are:

$$
f_{30}=12 \cdot 8 W^{-0.02} \quad(N=16, r=-0.23)
$$

and

$$
f_{37}=15 \cdot 6 W^{-0.04} \quad(N=12, r=-0 \cdot 13),
$$

in which $f$ is ventilation frequency in breaths $/ \mathrm{min}, W$ is body weight in $\mathrm{kg}, N$ is the number of species examined and $r$ is the least-squares correlation coefficient. Neither of these relationships shows a significant correlation of ventilation frequency with body weight $\left(P\right.$ at $30^{\circ} \mathrm{C}>0.4 ; P$ at $\left.37^{\circ} \mathrm{C}>0.5\right)$. Ventilation frequency is, therefore, independent of body weight and must be related to other factors. The mean of the observed values at $30^{\circ} \mathrm{C}$ is $18.7( \pm 2.7 \mathrm{~S} . \mathrm{E}$.) and, at $37^{\circ} \mathrm{C}, 22 \cdot 7$ ( $\pm 2 \cdot 6$ S.E.).

Saurian ventilation frequencies are considerably higher than any of those reported for snakes (Boyer, 1966; Dmi'el, 1972), turtles (Altland \& Parker, 1955; Jackson, 1971), or crocodilians (Boyer, 1966; Huggins et al., 1971), all of which have values of $1-5$ breaths/min at similar $T_{b}$. A differential of ventilation frequencies of this size between the reptilian orders is surprising because of the similarity of the rates of oxygen consumption in all these groups (see Bennett \& Dawson, 
1973). It is not completely unexpected in view of the greatly different morphological structures of the ventilatory apparatus in these animals. Compensatory adjustments in either tidal volume or oxygen extraction from pulmonary air must equalize this imbalance. Ventilation frequency at $37^{\circ} \mathrm{C}$ in lizards weighing $100 \mathrm{~g}-1 \mathrm{~kg}$ is very similar to that of non-passerine birds of equal size $(f=17-35)$ and considerably less than that of comparably sized mammals $(f=53-97)$ (Stahl, 1967; Lasiewski \& Calder, 1971). Ventilation frequency is inversely proportional to body size in both these groups, in contrast to lizards.

\section{Tidal volume in resting lizards}

Both lizards in this study possess a resting tidal volume which is relatively independent of $T_{\mathrm{b}}$. The thermal dependence of tidal volume is also low $\left(Q_{10}\right.$ $\leqslant 1.6$ ) in most other lizards investigated: E. cunninghami (Wilson, 1971), Lacerta spp. (Nielsen, 1961), S. obesus (Crawford \& Kampe, 1971), T. rugosa (Wilson, 1971 ) and $X$. vigilis (Snyder, 1971), as well as $S$. hispidus and $V$. gouldii. The only species for which a high thermal dependence of tidal volume $\left(Q_{10} \geqslant 2 \cdot 0\right)$ is reported are C. collaris (Templeton \& Dawson, 1963) and P. lesueuri (Wilson, 1971). Resting lizards do not, therefore, generally meet the increased demands for higher oxygen consumption at high $T_{\mathrm{b}}$ by increasing the amount of the lung area ventilated. An increment in either ventilation frequency or the percentage of oxygen extracted from ventilated air is responsible for the greater oxygen uptake.

Table 3-Tidal volume in Lizards

\begin{tabular}{lcccl}
\hline Species & $\begin{array}{c}\text { Weight } \\
(\mathrm{g})\end{array}$ & $\begin{array}{l}V_{\mathrm{T}}\left(30^{\circ} \mathrm{C}\right) \\
\left(\mathrm{cm}^{3} \text { air }\right)\end{array}$ & $\begin{array}{l}V_{\mathrm{T}}\left(37^{\circ} \mathrm{C}\right) \\
\left(\mathrm{cm}^{3} \text { air }\right)\end{array}$ & \multicolumn{1}{c}{ Reference } \\
\hline C. collaris & 30 & $0 \cdot 13$ & $0 \cdot 26$ & Templeton \& Dawson, 1963 \\
E. cunninghami & 253 & 0.94 & 1.03 & Wilson, 1971 \\
Lacerta spp. & 19 & $0 \cdot 29$ & $0 \cdot 29 *$ & Nielsen, 1961 \\
$P$. lesueuri & 585 & $1 \cdot 26$ & 1.92 & Wilson, 1971 \\
S. hispidus & 574 & 3.50 & 3.50 & This study \\
S. obesus & 140 & 1.45 & 1.40 & Crawford \& Kampe, 1971 \\
$T$. rugosa & 477 & $2 \cdot 37$ & $2 \cdot 68$ & Wilson, 1971 \\
V. goiuldii & 674 & $4 \cdot 17$ & $5 \cdot 76$ & This study \\
$X$. vgilis & 1.1 & 0.011 & $0.018 \dagger$ & Snyder, 1971 \\
\hline
\end{tabular}

* Extrapolated.

$+36^{\circ} \mathrm{C}$.

In contrast to ventilation frequency, tidal volume is dependent on body weight. Interspecific data on saurian tidal volume are presented in Table 3 , and the following regressions have been calculated for 30 and $37^{\circ} \mathrm{C}$.

$$
\begin{array}{ll}
V_{\mathrm{T}_{30}}=4.31 W^{0.85} & (N=9, r=0.96) \\
V_{\mathrm{T}_{37}}=4.93 W^{0.80} & (N=9, r=0.98)
\end{array}
$$


in which $V_{\mathrm{T}}$ is given in $\mathrm{cm}^{3}$ air (BTPS)/breath and $W$ is weight in $\mathrm{kg}$. Both these regressions are highly significant $(P<0.001)$ and the weight-dependent exponent, $b$, is almost identical to that relating metabolic rate to body weight in lizards: $b_{30}=0.83, b_{37}=0.82$ (Bennett \& Dawson, 1973). Tidal volume, therefore, appears to be the principal adjustment of ventilatory factors to weight-dependent changes in metabolism. Given the independence of ventilation frequency from body weight, these relationships suggest that oxygen extraction from the lungs also must be a weight-independent factor. The predicted interspecific thermal dependence of tidal volume is low ( $Q_{10}$ is 1.2 for a $1-\mathrm{kg}$ lizard).

Tidal volumes measured for turtles (Altland \& Parker, 1955; Jackson, 1971) and snakes (Dmi'el, 1972) range from two to six times the values predicted for lizards of equal size by Equation (3). Values for saurian tidal volumes are close to but generally less than those of mammals and are considerably less than those of birds $\left(V_{\mathrm{T}}\right.$ is $4.93,7.69$ and 13.2 for a $1-\mathrm{kg}$ lizard, mammal and bird, respectivelyStahl, 1967; Lasiewski \& Calder, 1971).

\section{Effect of activity on ventilation pattern}

The increased oxygen demands imposed by activity on the ventilation systems are met almost exclusively by increased tidal volume in both Varanus and Sauromalus. Ventilation frequency plays little or no role in this adjustment. A similar ventilatory response to activity was found in the lizards $E$. cunninghami, $P$. lesueuri and $T$. rugosa (Wilson, 1971): ventilation frequency increased by approximately one-half during activity and tidal volume increased by three- to sixfold. Similar increments were reported for four species of snakes during activity (Dmi'el, 1972). Such a response increases the inflated lung volume, perhaps facilitating oxygen exchange, while maximizing the time of lung inflation.

\section{Comparison of patterns of oxygen consumption and ventilation}

One of the purposes of this study was to determine whether ventilatory factors are closely correlated with metabolic oxygen consumption in Varanus and Sauromalus. These relationships can be determined by comparing the magnitude and pattern of minute volume and oxygen consumption during rest and activity (Figs. 1, 6 and 7). There is no indication from the magnitude of the values for minute volume that Varanus is able to consume twice as much oxygen during activity: minute volumes during activity are equal in these animals. Nor do the values of minute volume at rest indicate that these lizards consume equal amounts of oxygen at preferred $T_{\mathrm{b}}$ : minute volume is nearly twice as high in Varanus.

The patterns of these variables as functions of $T_{\mathrm{b}}$ are also poorly correlated. Most significantly, the plateau in oxygen consumption between 30 and $40^{\circ} \mathrm{C}$ in Sauromalus during activity is not accompanied by a corresponding plateau in active minute volume. It appears, therefore, that less oxygen is being extracted from the air ventilated and that a failure of the ventilatory system to provide adequate oxygen is a doubtful explanation for the extensive anaerobiosis exhibited during activity by Sauromalus. In addition, the thermal pattern of resting minute 
volume does not correspond to that of oxygen consumption in either Varanus or Sauromalus. In the former, metabolic rate exhibits a plateau between 30 and $40^{\circ} \mathrm{C}$ $\left(Q_{10}=1 \cdot 0\right)$ and minute volume has a $Q_{10}$ of $4 \cdot 3$. In the latter, oxygen consumption over this range of $T_{\mathrm{b}}$ is strongly temperature dependent $\left(Q_{10}=2.5\right)$ and minute volume is constant. It appears that little or no direct relationship exists between the thermal patterns of these factors, even though ventilation is the primary step in supplying the oxygen eventually consumed by the tissues.

A similar lack of correlation between metabolic and ventilatory factors was found by Wilson (1971) for two of the three species of lizards examined. The same conclusion was reached by Huggins et al. (1971) in an examination of resting metabolism and ventilation in Caiman sclerops: no significant correlation between these factors was found. They concluded that " . . . respiratory parameters are controlled by many factors other than specific oxygen requirements of the moment and ventilation and other respiratory variables probably serve ends other than that of oxygen supply and must be controlled ... by other mechanisms".

\section{Respiratory requirement and oxygen extraction in lizards}

The amount of oxygen extracted from the air ventilated may be estimated by the ratio of minute volume to oxygen consumption, the respiratory requirement (the ventilation quotient of Nielsen, 1961). This ratio may be thought of as the volume of air which must be taken into the lungs in order to supply a unit volume of oxygen to the tissues. A high respiratory requirement represents a poor capacity for oxygen extraction.

The respiratory requirements of Varanus and Sauromalus are given in Figs. 8 and 9 for resting and active animals, respectively. At most $T_{\mathrm{b}}$, Varanus at rest has a lower respiratory requirement than Sauromalus does. The increase in this

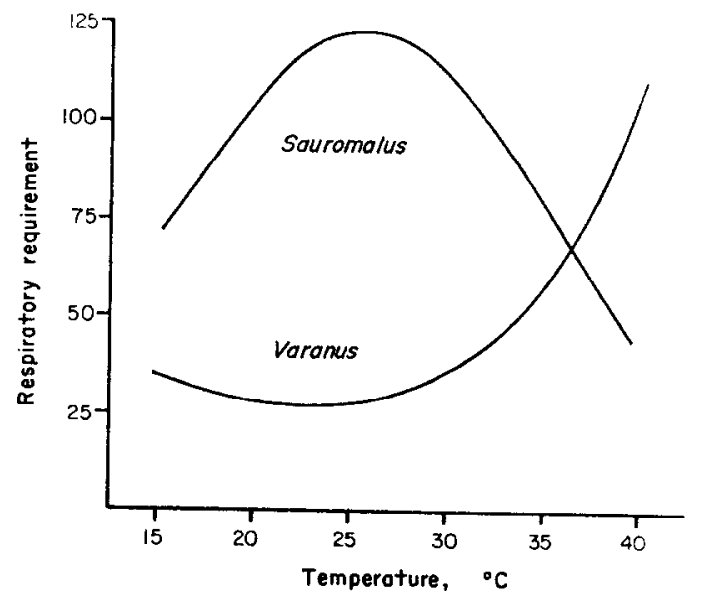

Fig. 8. Respiratory requirement of Sauromalus and Varanus under resting conditions. 
ratio for Varanus and decrease for Sauromalus at $T_{\mathrm{b}}$ above $30^{\circ} \mathrm{C}$ is a reflection of the plateau in oxygen consumption in the former and ventilation frequency in the latter. During activity, Varanus removes more oxygen at all $T_{\mathrm{b}}$ than Sauromalus. This differential is particularly high over the range of preferred $T_{b}$. At $40^{\circ} \mathrm{C}$, the respiratory requirement of Varanus is 44 , an extraction of 13.4 per cent of the oxygen ventilated; comparable values for Sauromalus are 98 and 6.0 per cent.

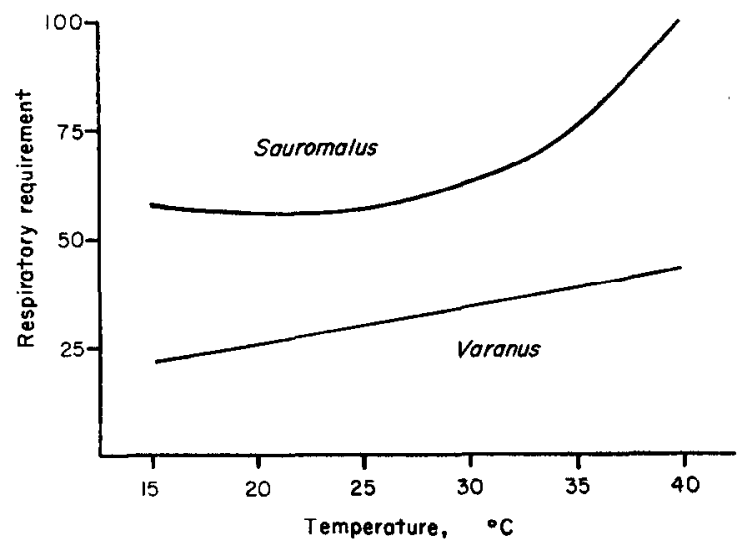

FIG. 9. Respiratory requirement of Sauromalus and Varanus during activity.

More efficient oxygen removal is, therefore, responsible for the greater oxygen consumption by Varanus during activity. The more complex lung structure with its greater surface area is undoubtedly involved in its higher capacity for gas exchange. This capacity permits Varanus to remain aerobic during sustained activity and to avoid the exhaustion inherent in anaerobic work.

Oxygen extraction by Varamus during activity increases above resting values at its preferred range of $T_{\mathrm{b}}$. This situation contrasts to that in all other reptiles examined, in which the respiratory requirement remains constant or increases: $S$. hispidus (Figs. 8 and 9), the lizards $E$. cunninghami, $P$. lesueuri and T. rugosa (Wilson, 1971) and the snakes Aspis cerastes, Coluber ravergieri, Spalerosophis cliffordi and Vipera palestinae (Dmi'el, 1972), This decrease may be the result of an inability to maintain higher extraction levels from the greater volume of air ventilated or may reflect less favorable loading conditions for the hemoglobin. Anaerobic metabolism in lizards causes a release of lactic acid into the blood which may overwhelm the capacity of the blood buffering systems and cause a decrease in blood pH (Bennett, 1971, 1973; Wilson, 1971). Such a decrement does not occur in Varanus but does in all other species examined. According to the Bohr effect, a decrement in $\mathrm{pH}$ decreases the affinity of hemoglobin for oxygen. In Sauromalus at $40^{\circ} \mathrm{C}$, this effect depresses the maximum possible saturation to only 70 per cent of its resting oxygen capacity and greatly decreases oxygen affinity and the interaction of hemoglobin subunits in the facilitation of oxygen loading. 
Varanus is able to avoid these adverse effects with superior blood buffers and a greater lung surface area (Bennett, 1973).

Increasing temperature generally increases the respiratory requirement of lizards, particularly in active animals (Figs. 8 and 9; Wilson, 1971). This may be partially the influence of a direct effect of temperature on the hemoglobin, decreasing its oxygen affinity. The oxygen capacity and affinity of the blood of both Sauromalus and Varanus are depressed by high temperature (Bennett, 1973).

\section{Oxygen extraction coefficients in reptiles, birds and mammals}

Sufficient data are now available to permit a comparative examination of the ability of reptilian, avian and mammalian lungs to extract oxygen from ventilated air. For purposes of comparison, measurements of respiratory requirement have been converted to oxygen extraction coefficients, the amount of oxygen extracted from oxygen ventilated (Table 4). At $35^{\circ} \mathrm{C}$, the most commonly measured value close to $T_{\mathrm{b}}$ of homeotherms, the mean extraction coefficient is 14.9 per cent

TABLE 4-OXYGEN EXTRACTION COEFFICIENTS OF RESTING LIZARDS

\begin{tabular}{|c|c|c|c|c|c|}
\hline \multirow[b]{2}{*}{ Species } & \multirow[b]{2}{*}{$\begin{array}{l}\text { Weight } \\
\text { (g) }\end{array}$} & \multirow{2}{*}{$\begin{array}{c}\text { Extraction } \\
\text { at } 35^{\circ} \mathrm{C} \\
\text { Per cent }\end{array}$} & \multicolumn{2}{|c|}{$\begin{array}{l}\text { Maximum } \\
\text { extraction }\end{array}$} & \multirow[b]{2}{*}{ Reference } \\
\hline & & & $\begin{array}{l}\text { Per } \\
\text { cent }\end{array}$ & $\begin{array}{c}T_{\mathrm{b}} \\
\left({ }^{\circ} \mathrm{C}\right)\end{array}$ & \\
\hline C. collaris & 30 & 17.2 & $17 \cdot 9$ & 40 & $\begin{array}{l}\text { Dawson \& Templeton, } 1963 \text {; } \\
\text { Templeton \& Dawson, } 1963\end{array}$ \\
\hline E. cunninghami & 253 & $12 \cdot 1$ & $13 \cdot 7$ & 40 & Wilson, 1971 \\
\hline Lacerta spp. & 19 & $8 \cdot 6$ & $8 \cdot 6$ & 35 & Nielsen, 1961 \\
\hline P. lesueuri & 585 & $15 \cdot 0$ & $15 \cdot 0$ & 35 & Wilson, 1971 \\
\hline S. hispidus & 574 & $7 \cdot 4$ & $14 \cdot 0$ & 40 & This study \\
\hline S. obesus & 140 & 29.9 & $29 \cdot 9$ & 35 & Crawford \& Kampe, 1971 \\
\hline T. rugosa & 477 & $24 \cdot 8$ & $25 \cdot 4$ & 32 & Wilson, 1971 \\
\hline V. gouldii & 674 & $9 \cdot 3$ & $19 \cdot 7$ & 23 & This study \\
\hline$X$. vigilis & $1 \cdot 1$ & $9 \cdot 8^{*}$ & $20 \cdot 8$ & 33 & Snyder, 1971 \\
\hline
\end{tabular}

$* 36^{\circ} \mathrm{C}$.

( \pm 2.6 S.E. $)$; no correlation exists between this factor and body weight $(P>0.5)$. A more meaningful comparative base is the maximum extraction coefficient during rest, regardless of $T_{\mathrm{h}}$, since other factors may affect the thermal pattern of extraction (as in Varanus, for example). The mean value for this is 18.3 per cent $( \pm 2.2$ S.E.). This factor is not correlated with body weight $(P>0.5)$ or $T_{\mathrm{b}}(P>0.5)$. There is a significant inverse correlation between ventilation frequency and extraction coefficient $(P<0.05$ by Spearman rank correlation). This relationship supports the hypothesis that the length of time of retention of pulmonary air is important in oxygen removal. Factors of lung morphology are also undoubtedly important in differential oxygen extraction. These coefficients are very similar 
to the mean of 14.0 per cent reported for four species of snakes by Dmi'el (1972). The only datum on a crocodilian is a value of 9.7 per cent for Caiman sclerops at $24^{\circ} \mathrm{C}$ (Huggins et al., 1971). This is not outside the range for saurian values; however, a temperature series would be valuable. Turtles may well have superior capacities of oxygen extraction: an oxygen extraction coefficient of 52.6 per cent was reported by Jackson (1971) for resting Pseudemys scripta elegans at $35^{\circ} \mathrm{C}$.

Comparable extraction coefficients for resting homeotherms are 23.0 per cent for birds (Lasiewski \& Calder, 1971) and 17.6 per cent for mammals (Stahl, 1967). The mean maximum coefficients for resting lizards, 18.3 per cent, is intermediate to these values. The amount of oxygen removed from inspired air by these groups is also independent of body weight (Lasiewski \& Calder, 1971), as it is in lizards. Nielsen (1961) believed that the high respiratory requirement of Lacerta in comparison to that of mammals was a reflection of its primitive lung structure. The surprising fact is that further data have shown that there is no difference in oxygen extraction coefficients in spite of the simple lung morphology of lizards.

The various factors associated with ventilation and oxygen consumption are compared among lizards, mammals and birds in Table 5. The data are given in the form of power law estimates relating the respiratory variable to body weight in

TABLE 5-COMParisons OF PARAMETER ESTIMATES OF RESPIRATORY VARIABLES AS A FUNCTION OF BODY WEIGHT IN RESTING LIZARDS, BIRDS, AND MAMMALS*

\begin{tabular}{|c|c|c|c|c|c|c|}
\hline & \multicolumn{2}{|c|}{ Lizards† } & \multicolumn{2}{|c|}{ Birds $\ddagger$} & \multicolumn{2}{|c|}{ Mammals $\ddagger$} \\
\hline & $a$ & $b$ & $a$ & $b$ & $a$ & $b$ \\
\hline $\begin{array}{l}\text { Ventilation frequency } \\
\text { (breaths/min) }\end{array}$ & $15 \cdot 6$ & -0.04 & $17 \cdot 2$ & -0.31 & $53 \cdot 5$ & $-0 \cdot 26$ \\
\hline $\begin{array}{l}\text { Tidal volume } \\
\text { (cm }{ }^{\mathrm{z}} \text { air BTPS/breath) }\end{array}$ & 4.93 & 0.80 & 13.2 & 1.08 & 7.69 & 1.04 \\
\hline 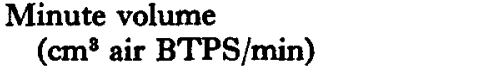 & 76.9 & 0.76 & 284 & 0.77 & 379 & 0.80 \\
\hline $\begin{array}{l}\text { Respiratory requirement } \\
\text { (cm }{ }^{3} \text { air BTPS } / \mathrm{cm}^{3} \mathrm{O}_{2} \text { STPD) } \\
\text { Oxygen extraction coefficient }\end{array}$ & $37 \cdot 7$ & 0.05 & $25 \cdot 1$ & 0.05 & $32 \cdot 7$ & 0.04 \\
\hline $\begin{array}{l}\text { (per cent) } \\
\text { Metabolic rate }\end{array}$ & $15 \cdot 3$ & 0.05 & $23 \cdot 0$ & 0.05 & $17 \cdot 6$ & $0 \cdot 04$ \\
\hline$\left(\mathrm{cm}^{3} \mathrm{O}_{2} \mathrm{STPD} / \mathrm{min}\right)$ & $2.04 \S$ & $0.82 \S$ & $11 \cdot 3$ & 0.72 & $11 \cdot 6$ & $0 \cdot 76$ \\
\hline
\end{tabular}

* Values of $a$ and $b$ refer to parameter estimates of the equation $y=a W^{b}$, in which $W$ is body weight in $\mathrm{kg}, a$ is the predicted value of the variable for a $1-\mathrm{kg}$ animal, and $b$ is the slope of the function on a double-logarithmic plot. Values of $b$ in the range of -0.05 to +0.05 are probably not significantly different from 0.0 .

$+35-37^{\circ} \mathrm{C} T_{b}$.

$\ddagger$ Avian and mammalian data are taken from Lasiewski \& Calder, 1971. Mammalian data were originally derived from Stahl, 1967.

\& Bennett \& Dawson, 1973. 
the equation $y=a W^{b}$, in which $W$ is body weight in $\mathrm{kg}$ and $a$ and $b$ are empirically derived constants representing the predicted value for the respiratory variable for a $1-\mathrm{kg}$ animal $(a)$ and the slope of this function on a $\log$ variable vs. $\log W$ graph (b). A more extensive discussion of the formulation and utility of allometric analysis of respiratory variables is given by Stahl (1967) and Lasiewski \& Calder (1971). Data on ventilation frequency, tidal volume and oxygen consumption are used to calculate the remaining variables. Although the percentage of oxygen extraction is equal in these three groups, lizards ventilate a smaller volume of air in an equal time period and consequently remove a smaller total volume of oxygen in an equal time period. The higher ventilation rates of the homeotherms are principally the result of a greater ventilation frequency in mammals and a greater tidal volume in birds.

An intriguing question is whether saurian lungs are capable of this high oxygen removal only because minute volume is low or whether these high oxygen extraction coefficients can be maintained at higher ventilation rates. Is there a reserve capacity for oxygen extraction or are saurian lungs efficient only at resting ventilation rates? This question bears directly on the physiological role of the evolutionary changes in lung structure in the birds and mammals. Are the more complex lungs of these animals, with their greater surface areas, a response to the increased resting metabolic rate associated with homeothermy or could oxygen extraction be kept at sufficiently high levels even with simple lungs to compensate for this five- to six-fold increment in oxygen consumption? In the latter case, the more complex lung morphology might be viewed as a response to the energetic demands of increased activity, either permitting high oxygen extraction at even greater ventilation rates or the release of carbon dioxide generated either aerobically or anacrobically via the bicarbonate buffering system.

This problem is not amenable to direct manipulation of ventilation rate in resting reptiles, even if such artifical respiration were technically feasible. Oxygen consumption follows the metabolic rate of the tissues and the extraction coefficient would probably decline to maintain the new dynamic balance between ventilation and metabolism. An indication of this capacity may be obtained from the extraction coefficient of active animals. This examination is not ideal since activity imposes an added stress on the respiratory system through the Bohr effect on hemoglobin and might be expected to decrease oxygen extraction anyway. However, we may examine the percentage of oxygen extracted by several species of lizards during activity at ventilation rates equivalent to those of resting mammals of comparable size. These rates are about five times resting saurian minute volumes at $37^{\circ} \mathrm{C}$ (see Table 5). The following percentages are thus obtained: E. cunninghami, 8.3 per cent; $P$. lesueuri, 12.6 per cent (Wilson, 1971); S. hispidus, 9.0 per cent; $V$. gouldii, 15.4 per cent. T. rugosa never achieves resting mammalian minute volumes, but at 78 per cent of these levels, oxygen extraction is 19.6 per cent (Wilson, 1971). The values are well within the range of extraction coefficients for resting lizards at $35^{\circ} \mathrm{C}$ (see Table 4). Although these systems are pushed nearly to their limits of oxygen consumption and are further stressed by unfavorable 
loading conditions for oxygen due to activity, oxygen extraction remains relatively high. These relations suggest that reptilian lungs, in spite of their simple structure, would be adequate to supply the oxygen required by a resting homeotherm, providing an appropriate increment in minute volume. The complex lung structure of birds and mammals must, therefore, be in greatest part a response to the increased demands of oxygen aquisition and/or carbon dioxide release during activity in the ancestors of these groups.

Acknowledgements-This study is a portion of a doctoral dissertation submitted to the Department of Zoology, University of Michigan. Financial support was provided by four N.S.F. Graduate Fellowships (1966-70), N.S.F. Grant GB-3656 to Professor W. R. Dawson, the Graduate Student Research Fund of the Horace H. Rackham School of Graduate Studies and N.S.F. Grant GB-8212 to Professor N. G. Hairston for research in Systematic and Evolutionary Biology. I am indebted to the Departments of Zoology at the Universities of Michigan and Western Australia for use of their facilities. I wish to thank Professor William R. Dawson for his help and advice throughout my graduate tenure. I also thank Professor P. Licht for critically reading the manuscript.

\section{REFERENCES}

Altlañd P. D. \& Parker M. (1955) Effects of hypoxia upon the box turtle. Am. F. Physiol. $180,421-427$.

Andersen H. T. (1961) Physiological adjustments to prolonged diving in the American Alligator Alligator mississippiensis. Acta physiol. scand. 53, 23-45.

Bartholomew G. A. \& Tucker V. A. (1964) Size, body temperature, thermal conductance, oxygen consumption, and heart rate in Australian varanid lizards. Physiol. Zoöl. 37, 341-354.

BeNnETT A. F. (1971) Oxygen transport and energy metabolism in two species of lizards, Sauromalus hispidus and Varanus gouldii. Ph.D. thesis, University of Michigan, Ann Arbor.

Bennett A. F. (1972a) A comparison of activities of metabolic enzymes in lizards and rats. Comp. Biochem. Physiol. 42B, 637-647.

BENNETT A. F. (1972b) The effect of activity on oxygen consumption, oxygen debt, and heart rate in the lizards Varanus gouldii and Sauromalus hispidus. F. comp. Physiol. 79, 259-280.

BENNETT A. F. (1973) Blood physiology and oxygen transport during activity in two lizards, Varanus gouldii and Sauromalus hispidus. Comp. Biochem. Physiol. 46A, 673-690.

Bennett A. F. \& DAwson W. R. (1972) Aerobic and anaerobic metabolism during activity in the lizard Dipsosaurus dorsalis. F. comp. Physiol. 81, 289-299.

Bennett A. F. \& Dawson W. R. (1973) Metabolism. In Biology of the Reptilia (Edited by Gans C.), Physiology A, Vol. 5. Academic Press, New York. (In press.)

BenNetT A. F. \& Licht P. (1972) Anaerobic metabolism during activity in lizards. $\mathcal{F}$. comp. Physiol. 81, 277-288.

BOYER D. R. (1966) Comparative effects of hypoxia on respiratory and cardiac function in reptiles. Physiol. Zoöl. 39, 307-316.

BOYER D. R. (1967) Interaction of temperature and hypoxia on respiratory and cardiac responses in the lizard, Sauromalus obesus. Comp. Biochem. Physiol. 20, 437-447.

Crawford E. C., JR \& KaMPe G. (1971) Physiological responses of the lizard Sauromalus obesus to changes in ambient temperature. Am. F. Physiol. 220, 1256-1260. 
DAwson W. R. (1960) Physiological responses to temperature in the lizard Eumeces obsoletus. Physiol. Zoöl. 33, 87-103.

Dawson W. R. \& Bartholomew G. A. (1958) Metabolic and cardiac responses to temperature in the lizard Dipsosaurus dorsalis. Physiol. Zoöl. 31, 100-111.

Dawson W. R. \& Templeton J. R. (1963) Physiological responses to temperature in the lizard Crotaphytus collaris. Physiol. Zoöl. 36, 219-236.

Dawson W. R. \& Templeton J. R. (1966) Physiological responses to temperaturc in the alligator lizard, Gerrhonotus multicarinatus. Ecology 47, 759-765.

DMI'EL R. (1972) Effect of activity and temperature on metabolism and water loss in snakes. Am. 7. Physiol. 223, 510-516.

Francis C. \& Brooks G. R. (1970) Oxygen consumption, rate of heart beat and ventilatory rate in parietalectomized lizards, Sceloporus occidentalis. Comp. Biochem. Physiol. 35, 463-469.

Hill R. W. (1972) Determinaton of oxygen consumption by use of paramagnetic oxygen analyzer. F, appl. Physiol. 33, 261-263.

Hudson J. W. \& Bertram F. W. (1966) Physiological responses to temperature in the ground skink, Lygosoma laterale. Physiol. Zoöl. 39, 21-29.

Huggins S. E., VAlentinuzzi M. E. \& Hoff H. E. (1971) Relationship of oxygen consumption to heart rate and respiratory parameters in Caiman sclerops. Physiol. Zoöl. 44, 98-111.

JACKson D. C. (1971) Effect of temperature on ventilation in the turtle, Pseudemys scripta elegans. Respir. Physiol. 12, 131-140.

KrrschFeld U. (1970) Eine Bauplananalyse der Waranlunge. Zool. beit. N.F. 16, 401-440.

LAsIewski R. C. \& CALDER W. A., JR. (1971) A preliminary allometric analysis of respiratory variables in resting birds. Respir. Physiol. 11, 152-166.

Mertens R. (1942) Die Familie der Warane (Varanidae). I. Allgemeines. Abh. Senck. Naturforsch. Gesellsch. 462, 1-116.

Mrlanı A. (1894) Beiträge zur Kenntnis der Reptilienlunge. I. Lacertilia. Zool. Yb. 7, 545-592.

Moberly W. R. (1963) Hibernation in the desert iguana. Physiol. Zoöl. 36, 152-160.

MoberLy W. R. (1968) The metabolic responses of the common iguana, Iguana iguana, to activity under restraint. Comp. Biochem. Physiol. 27, 1-20.

Murrish D. E. \& VANCE V. J. (1968) Physiological responses to temperature acclimation in the lizard Uta mearnsi. Comp. Biochem. Physiol. 27, 329-337.

Nielsen B. (1961) On the regulation of the respiration in reptiles. I. The effect of temperature and $\mathrm{CO}_{2}$ on the respiration of lizards (Lacerta). $\mathcal{F}$. exp. Biol. 38, 301-314.

Pough F. H. (1969) Physiological aspects of the burrowing of sand lizards (Uma, Iguanidae) and other lizards. Comp. Biochem. Physiol. 31, 869-884.

Romer A. S. (1956) Osteology of the Reptiles. University of Chicago Press, Chicago.

SNYDER G. K. (1971) Adaptive value of a reduced respiratory metabolism in a lizard. A unique case. Respir. Physiol. 13, 90-101.

Stahl W. R. (1967) Scaling of respiratory variables in mammals. F. appl. Physiol. 22, $453-460$.

Steggerda F. R. \& Essex H. E. (1967) Circulation and blood pressure in the great vessels and heart of the turtle (Chelydra serpentina). Am. F. Physiol. 190, 320-326.

Templeton J. R. \& Dawson W. R. (1963) Respiration in the lizard Crotaphytus collaris. Physiol. Zoöl. 36, 104-121.

Tucker V. A. (1966) Oxygen transport by the circulatory system of the green iguana (Iguana iguana) at different body temperatures. F. exp. Biol. 44, 77-92.

White F. N. (1959) Circulation in the reptilian heart (Squamata), Anat. Rec. 135, 129-134.

WILson K. J. (1971) The relationships of activity, energy, metabolism, and body temperature in four species of lizards. Ph.D. thesis, Monash University, Clayton. 
WolF S. (1933) Zur Kenntnis von Bau und Funktion der Reptilienlungen. Zool. צb. 57, 139-190.

Key Word Index-Activity; aerobic scope; anaerobiosis; lizard; lungs; minute volume; oxygen consumption; oxygen extraction coefficient; reptile; respiratory requirement; Sauromalus; temperature; tidal volume; Varanus; ventilation; ventilation frequency. 